\title{
The Role of the Ambon City's Population and Civil Registration Office in Controlling Incoming Migration
}

\author{
Rahmawati Sururama ${ }^{1}$, Tiara Nanuru ${ }^{2}$ \\ ${ }^{1}$ Department of Local Government Administration, Faculty of Government Management, \\ Institut Pemerintahan Dalam Negeri (email: rahmawatisururama@ipdn.co.id), \\ 2 Regional staffing office, North Maluku Province (email: tiara96.tn@gmail.com)
}

\begin{abstract}
The objectives of this study are to find out the role of the Ambon City's Population and Civil Registration Office in Controlling Incoming Migration and to find out the obstacles faced by the Ambon City's Population and Civil Registration Office in Controlling Incoming Migration. This study used a qualitative descriptive research method. Data Collection was obtained through observation, interview, and documentation. Data were analyzed using data reduction, display data, and verification. Primary and secondary data were used as the sources for analysis. The informants in this study were the chief of the Population and Civil Registration Office Ambon City and the Population Monitoring and Control Division, as well as the migrants. Ambon City's Government, through the Population and Civil Registration Office, has carried out its duties as regulated by the Mayor of Ambon Regulation No. 17/ 2009 article 14 paragraph 2, namely: Coordinating the monitoring of urbanization of population and supervising the registration of population mobility flows. The constraints faced by the Ambon City population and civil registration office, namely: Most of the population who migrated to Ambon City did not report themselves so the authorities had difficulty monitoring the flow of urbanization and monitoring population mobility; inspected and supervised residents, who have not lived in Ambon city for six months, have moved to other areas; there is no effort and awareness of people who have been examined and under supervision to change by reporting personal data to the government.
\end{abstract}

\section{Keywords:}

role; administration of population; migration

\section{Introduction}

The Indonesian government, in accordance with the mandate of the 1945 Basic Law, must protect, prosper the entire nation of Indonesia and all the bloodshed of Indonesia. Based on this, the government, through various programs, seeks to hold the mandate to lead a prosperous and successful nation. However, it is undeniable that many obstacles were also faced by the Indonesian government to implement their programs due to their geographical location and higher population growth, which was not followed by equal distribution of population in each region.
It is instructive that recent debates on climate change and migration have tended to focus on migration as a problem or threat (Hartmann, 2010). For example, a common the mein much media, policy and campaign group discourse on climate change is that future environmental change will lead to the displacement of millions of people as "environmental refugees" or “environmental migrants" (Black et al., 2011).

In 2018, the population of Indonesia was $265,015,000$, based on the data provided by the Central Bureau of Statistics (BPS), and the most population was in West Java, with a total of $48,683,700$ inhabitants. This number is 
about $18 \%$ of Indonesia's total population. West Papua is the province with the least population of 937,500 , whereas Maluku has a population of $1,773,776$, which are distributed at eleven city districts (Table 1).

Table 1.

The Population of Maluku Province According to Regency/City 2018

\begin{tabular}{clc}
\hline No & \multicolumn{1}{c}{ Regency/City } & $\begin{array}{c}\text { Number of } \\
\text { population }\end{array}$ \\
\hline 1 & West region of southeast maluku & 112,429 \\
2 & Southeast Maluku & 99,591 \\
3 & Central Maluku & 372,529 \\
4 & Buru & 139,658 \\
5 & Aru Islands & 95,005 \\
6 & West region of seram & 170,969 \\
7 & East region of seram & 113,180 \\
8 & Soutwest Maluku & 72,840 \\
9 & South Buru & 62,271 \\
10 & Ambon City & 461,699 \\
11 & Tual City & 73,605 \\
& Maluku Province & $1,773,776$ \\
\hline
\end{tabular}

Source: BPS, Maluku Migration Statistics

From the data shown above, the highest population from 11 regencies/cities in Maluku is at Ambon City, which has been caused by higher migration. From the results of this study, a higher migration in Ambon City is caused by domestic migration from Urbanization, Forensen, and Tourism factors. There are several types of domestic migration; Migration, Urbanization, Ruralization, Evacuation, Forensen, and Tourism, which now becomes a trend of tourists who want enjoying tourist destinations at a place or country for a long time. Especially in Maluku, the development of the tourism sector continued to show positive results, it was noted, throughout 2018; the number of tourist arrivals in Maluku increased by $20 \%$ over the previous year (Dinas Pariwisata Maluku, 2018). Migration is a crucial issue for Indonesia due to the uneven population distribution. One of the reasons is people prefer to stay in the city than in the villages, with their assumption that in the city they can get a job easily and live a better life.
However, the migration of people was not followed by the awareness of the individual to report to the local government, although it has been instructed by Law No. 24/2013 (Government of The Republic of Indonesia, 2013), which describes Population Administration through article 15 paragraph: (1) "Residents of Indonesian who move within the territory of the Unitary State of the Republic of Indonesia must report to the Executing Agency in the area of origin to obtain a Moving Certificate", (2) "Moving as referred to in paragraph (1) is the domicile of the population at the new address for more than 1 (one) year or based on the needs of the concerned for less than 1 (one) year", (3) "Based on the Moving Certificate referred to in paragraph (1), the concerned population is obliged to report to the Executing Agency in the destination area for the issuance of a Certificate of Moving Coming", (4) "A Certificate of Moving Coming as referred to in paragraph (3) is used as the basis for changes or issuance of family card (KK) and identity card (KTP) for the relevant residents.

In general, migration causes problems in Ambon City government, especially in the framework of population registration, which will eventually lead to policy being made by the Ambon City government in order to improve people's welfare, as stated in Law No. 24/2013 on changes to Law No. 23/2006 (Government of The Republic of Indonesia, 2013) concerning the Population Structural Agreement in article 15 paragraph 11, namely: "Population Administration, namely a series of structuring and regulating activities in the issuance of documents and Population Data through Population Registration, Civil Registration, Population Administration information management and the utilization of results for public services and development of other sectors."

There are two characteristics of population movement or mobility - permanent and nonpermanent. Permanent resettlement must 
report to the relevant agencies, in this case, the Office of Population and Civil Registry, to obtain an upcoming transfer certificate to change their personal data on ID cards. At the same time, they can be officially registered as a resident of Ambon City while the transfer of non-permanent residents is regulated in the Minister of Home Affairs Regulation No. 14/2015 (Government of The Republic of Indonesia, 2015) concerning Guidelines for Collecting Non-Permanent Population Data Article 1 paragraph 3, which describes that "permanent residents are residents of Indonesian citizens who live outside the regency/ city whose permanent residence differs from the address on their identity card (KTP-el) and do not intend to move permanently," while Article 3 paragraph 1 and 2 describe that each resident who makes a transfer will be recorded by the Office of Population and District/City Civil Registration at least 6 (six) months.

The population status of Ambon City is very high compared with other regencies/ cities in Maluku Province. The number of inmigration in Ambon City can be seen in Table 2.

Table 2.

Total Incoming Migration Each Regency/ City in 2010

\begin{tabular}{lccc}
\hline \multirow{2}{*}{ Regency / City } & \multicolumn{3}{c}{ Incoming Migration } \\
\cline { 2 - 4 } & Man & Women & Total \\
\hline Districts & 4,382 & 3,714 & 8,096 \\
Southeast West Maluku & 5.367 & 5,591 & 10,958 \\
Southeast Maluku & 23,570 & 21,978 & 45,548 \\
Central Maluku & 13,291 & 11.907 & 25,198 \\
Buru & 8,854 & 6,944 & 15,789 \\
Aru Islands & 11,774 & 11,519 & 23,293 \\
West Seram & 6,467 & 5,450 & 11,917 \\
Eastern Seram & 1,551 & 1,092 & 2,643 \\
Southwest Maluku & 2.367 & 2,028 & 4,395 \\
South Buru & \multicolumn{4}{c}{} \\
City & 56,576 & 56,139 & 112,715 \\
Ambon & 9,412 & 9.312 & 18,724 \\
Tual & \multicolumn{4}{c}{ Migration Statistics } \\
Source: BPS, Maluku & \multicolumn{3}{c}{ Mopulation Census 2010) }
\end{tabular}

In-migration is the entry of residents into an area of destination. In Table 1.2, it can be seen that the rate of lifetime in-migration in Ambon City is higher than other districts/ cities. While recent migrants are residents who moved past the limits of district/city role in the last five-year period before enumeration, as can be seen Table 3 .

Table 3.

Risen Entry Migration by Regency / City

\begin{tabular}{lrrr}
\hline \multirow{2}{*}{ Regency / City } & \multicolumn{3}{c}{ Incoming Migration } \\
\cline { 2 - 4 } & Man & Women & Total \\
\hline Districts & & & \\
Southeast West Maluku & 1,864 & 1,457 & 3,321 \\
Southeast Maluku & 2,447 & 2,397 & 4,844 \\
Central Maluku & 5,017 & 4,549 & 9,566 \\
Buru & 1,343 & 1,232 & 2,575 \\
Aru Islands & 2,619 & 2,089 & 4,708 \\
West Seram & 3.126 & 2,979 & 6.105 \\
Eastern Seram & 3.442 & 2,909 & 6,351 \\
Southwest Maluku & 652 & 516 & 1,168 \\
South Buru & 1,242 & 1,047 & 2,289 \\
City & \multicolumn{4}{c}{} \\
Ambon & 12,726 & 12,877 & 25,603 \\
Tual & 2,868 & 2,646 & 5.514 \\
\hline Source: BPS, Maluku & Migration Statistics \\
\multicolumn{4}{c}{ (Population Census 2010) }
\end{tabular}

The density of Ambon city results in high unemployment rates, and perpetrators of economic crimes, and create some slum areas. Migration is often held responsible for the disruption of traditional kinship systems and care structures, the loss of community solidarity or the undermining of their "sociocultural integrity", and the breakdown of traditional institutions regulating village life and agriculture. The above is the responsibility of the Ambon city Government through the Population and Civil Registration Office, according to its main duties and functions (De Haas, 2010). From the description above, the objectives of this study are to find out the role of the Ambon city's Population and Civil Registration Office in controlling incoming migration and to find out the obstacles faced 
by the Ambon city's Population and Civil Registration Office in controlling incoming migration.

\section{Literature Review \\ Role}

According to Duverger (2010), "Roles are attributes as a result of status, and behaviors that are expected by other members of the community towards holders of status, in short, the same role as the source of information from the status" (p. 102). According to Soekanto (2010), "Role is a dynamic aspect of the position. If a person exercises his rights and obligations in accordance with his position, he carries out a role. Everyone has different kinds of things that come from the patterns of life. It also means that the role determines what he does for the community and what opportunities the community gives him. The importance of the role is because it regulates a person's behavior. The role of causing someone at certain limits can predict the actions of others" (p. 212).

Furthermore, Levinson, as cited in Soekanto (2010), stated that the role includes three things: norms that are related to a person's position or place in society, a series of rules that guide a person in community life, and a concept of what can be done by individuals in society as an organization (p. 213)

Ambon City Population and Civil Registry Office in carrying out its role refers to Ambon Mayor Regulation No. 17/ 2009 (Ambon City's Government, 2009) concerning job description of the Structural Position in Ambon City Population and Civil Registration Office article 14 paragraph (2) section c and d, namely: Population Monitoring and Control Sector in charge of Coordinating the implementation of supervision of registration of Indonesian citizens and foreigners and monitoring the flow of urbanization of the population and supervising the registration of the flow of mobility of residents of Indonesian citizens and foreigners at each entrance of the city.

\section{Government}

According to W. S. Sayre in Syafiie (2011), Government is the organized agency of the state, expressing and exerting its authority. Whereas According to Ndraha (as cited in Labolo, 2011, p. 35-36), in carrying out State duties, the government has two basic functions, namely: Primary functions or service functions and Secondary functions or empowerment functions.

"The primary function is the function of the government as a provider of public services that cannot be privatized, including security services, civil services, and bureaucratic services. Meanwhile, secondary functions are as providers of needs and demands that are governed for goods and services that they are unable to fulfill themselves because they are still weak and powerless, including provision and development."

\section{Population Administration}

Republic of Indonesia Law No. 24/2013 concerning Amendments to Law No. 23/2006 concerning Population Administration states that "Population Administration is a series of structuring and controlling activities in the issuance of documents and Population Data through Population Registration, Civil Registration, Administration information management Population and utilization of results for public services and other sector development."

\section{Migration}

According to Mantra, Migration is the movement of resident who cross the borderline origin to other areas with the aim of settling in the destination (Mantra, 2013, p. 173). According to Lee, as cited in Mantra (2013, p. 181), the migration process is influenced by four factors: individual factors, factors found in the area of origin, factors found in the destination, and obstacles between the area of origin and the destination. 
Todaro (1979) migration is regarded as a rational action, maximizing the individual's net benefits (Haug, 2008). Human capital is a determining factor in migration decisions, as the qualification level correlates with the probability of finding a job and with the wage level at the place of destination.

\section{Methods}

This study uses a qualitative descriptive research method. The qualitative research method is the research method based on the philosophy of positivism, used to research on the condition of a natural object (as an opponent is an experiment), where the researcher is a key instrument (Sugiyono, 2013). Data were collected throughout observation, interview, and documentation. Data were analyzed using data reduction, data display, Conclusion drawing/Verification. In this study, primary and secondary data were used. The informants in this study were the chief of the Population and Civil Registration Office Ambon City and the Population Monitoring and Control Division, as well as the migrants.

\section{Research Novelty}

In previous studies or journals that described migration, the author cited as a comparison material, namely, research conducted by Sunarto (1991) in Population, Universitas Gadjah Mada Population and Policy Journal entitled Impact of Circular Migration on the Village of Origin of Migrants, from the results of the study said that migration has a positive effect on the village of origin, namely improving household welfare, as a buffer against social life, improving the way of managing agricultural land, and increasing the circulation of money in the village.

While the journal entitled Migration Analysis of the population to the village of Ndokumsiroga, Simpang Empat Sub-District, Karo Regency, written by Lumbantoruan (2009) in the Geography journal, said that the positive impact of rural migration is increasing economic conditions in terms of increasing funding for regional development, creating kinship between indigenous people and migrants through a process of renewal in various aspects of life, and the creation of cooperative relations in the development of village businesses. The driving factor for migrants to the village is due to economic, social, political factors.

The results of research or journals described above relate to migration to villages, while journals that can be used as other comparisons that talk about inward migration into the city are journals or research entitled Socio-demographic profile of socioeconomically disadvantaged internal migrants in Delhi, written by Yadlapalli, Chandrakant, \& Bontha (2014), who researched migration in the City of New Delhi India with the results of research which is the dominant factor that influences the occurrence of migration from the village to the city of New Delhi, namely livelihoods, because poverty in the villages is encouraged to find work in the city by expecting that by living in a city they will get a better life, in fact, the migration done has a negative impact on migrants, namely the unavailability of housing or adequate and decent housing, inappropriate/low employment, health and education services minimum, and low political representation.

If we compare the research or journals described above with research conducted by the author, it will open horizons and change people's mindsets about cities that can promise a better life, because from the results of the research, the authors found that migrants who do migrate to Ambon have a negative impact on migrants themselves and the city government. The negative impacts that arise from the migration are the emergence of slums caused by migrants who do not have a permanent or decent place to live, increase in crime rate due to economic pressure, and health 
and education factors that are not guaranteed. While the driving factors in migrating to the city are complete facilities, both from entertainment facilities, trade, education, and office centers, convenience in transportation, expecting to get a proper education, looking for jobs, tourism. The results of this study are almost the same as the results of research by Yadlapalli, Chandrakant, Bontha (2014), but what distinguishes this research directly leads to policy makers, the Ambon city government, through the population and civil registration office in carrying out their duties in monitoring and controlling the population movement. Using accurate data, Ambon city government can make policies, especially in order to improve the welfare of Ambon city residents.

\section{Result and Discussion}

Incoming migration is the entry of residents to a destination. Incoming migration that occurred in Ambon City based on the results of the researchers' observation is very high and this is seen from the rapid development, with the opening of new shopping centers, offices that are increasing, places of business increasingly diverse, and public facilities such as health and public transportation growing in the past five years has made the city of Ambon increasingly ogled by residents around it as a destination to migrate.

Based on the results of the interviews obtained from the Head of the Population Supervision and Control Division (Monday, January 23, 2017) - it is not much different from the observations of researchers - the Head of the Population Supervision and Control Division explained that the population movement from village to city in Maluku Province is very high; this is because urban areas, in this case, Ambon City, has complete facilities, including educational facilities that have national accredited A standards, so graduates High school/vocational school from the surrounding area will continue their studies in Ambon. In addition, farmers who live around the city of Ambon who cannot sell in their villages compete to come to Ambon City to sell their agricultural products. They came in the morning and returned to the area in the afternoon. This resulted in density and congestion that occurred every day in Ambon Mardika Market. Besides that, residents who migrate to Ambon City are also tourists who want to travel to Ambon. Some of them are foreign nationals. Migration is one livelihood strategy that households in eco-logically vulnerable communities pursue to diversify their income sources and to overcome the adverse welfare effects of social, economic, and institutional constraints in their places of origin (de Brauw \& Harigaya, 2007). According to Stark \& Bloom (1985), Migration increases household income and smooth income fluctuations, mainly through remittances (Nguyen, Raabe, \& Grote, 2015).

Next is the Head of the Ambon City Population and Civil Registration Office; when interviewed (Wednesday, January 25, 2017), he said the migration that occurred in Ambon City was very high because Ambon City had an attraction as a trade center and education center. The lack of entertainment in the village is also the reason why many people migrate to Ambon City, even though basically they are residents registered in other districts. Incoming migration that occurred in Ambon City was dominated by students who wanted to continue their studies and job seekers.

Migrant work is one component of an inter-locking livelihood, where income generation in the city must be understood in the context of livelihoods 'back home'. Children, futures, parents, identities, and aspirations remain rooted in the countryside, even while these migrants live and work in the city (Anh, Rigg, Huong, \& Dieu, 2012).

Article 15 paragraph (1), (2), (3), and (4) Law Number 23 Year 2006 jo. Law Number 24 of 2013 (Government Of The Republic 
Of Indonesia, 2013) concerning Population Administration explains that:

Paragraph (1) "Residents of Indonesian Citizens who move within the territory of the Unitary State of the Republic of Indonesia must report to the Implementing Agency in the area of origin to obtain a Moving Certificate." Paragraph (2) "Moving as referred to in paragraph (1) is domiciled by the Population at the new address for more than 1 (one) year or based on the needs of the concerned for a period of less than 1 (one) year." Paragraph (3) "Based on the letter of moved as referred to in paragraph (1) the concerned population is obliged to report to the Implementing Agency in the destination area for issuance of the Certificate of Moving Come." Paragraph (4) "Come Moving Certificate as referred to in paragraph (3) shall be used as the basis for changes or issuance of KK and KTP for the relevant Population."

Residents who move within the territory of Indonesia, in this case, move to a place of residence, must report themselves to the implementing agency to obtain a letter of moved. In fact, the residents who moved to Ambon City did not take care of the letter moved, in this case they wanted to stay in Ambon City for more than 1 year. Often they come without taking care of the transfer from the area of origin so that they are still listed as residents of the area of origin. When he had lived for a while and wanted to do an affair, which had to include evidence that the resident was a resident who was domiciled in the city of Ambon, then they arranged a direct transfer letter in the destination area. Minimal knowledge about transfer procedures has made it difficult to take care of the transfer process because they do not know what is needed and what to do when they want to move, even though the procedure is clearly stated in the rules.

But for Foreign residents who want to travel to Ambon City, they have been doing the procedure properly because no significant violations have been found. Based on Article 17 of Law No. 23/2006 jo. Law No. 24/2013 (Government Of The Republic Of Indonesia, 2013) concerning Population Administration, namely :

Paragraph (1) "Foreigners who have a Limited Stay Permit and Foreign Persons who have Permanent Stay Permits who move within the territory of the Unitary State of the Republic of Indonesia must report their plans of transfer to the Implementing Agency in the area of origin." Paragraph (2) "Based on the report as referred to in paragraph (1) the Implementing Agency registers and issues a Certificate of Moving Come." Paragraph (3) "Foreigners as referred to in paragraph (1) report arrivals to the Implementing Agency in the destination area no later than 30 (thirty) days after the issuance of the Certificate of Moving Come." Paragraph (4) "Come Moving Certificate as referred to in paragraph (2) is used as the basis for amendment or issuance of family card (KK), identity card (KTP), or the relevant residence certificate for foreigners."

Related to handling foreigners, the Population and Civil Registration Office of Ambon City coordinates with the Ambon City Immigration Office. Coordination was carried out in the form of equating data with foreigners who came and who reported themselves at the Ambon City Population and Civil Registration Service.

In the interview, the researcher made Lee's theory (1966) as a benchmark in describing the migration process. As quoted by Mantra (2013, pp. 180-181), Lee, in his article entitled A Theory of Migration, revealed that: 
"The volume of migration in one region develops according to the diversity of regions within the region. If you describe in the area of origin and destination, there are positive (+), negative (-) factors, and there are neutral factors (o). Positive factors are factors that provide a favorable value if living in the area, for example in the area there are schools, employment opportunities, and a good climate. While negative factors are factors that give a negative value to the area concerned so that someone wants to move from that place. The difference in cumulative values between the two places tends to cause a population immigration flow."

A research from china, which used general health questionnaires to identify the factors that affect the subjective well-being of rural workers, migrants, and local urban workers in China - the research finds that the well-being of migrants positively depends on the length of the migration period, the quality of working conditions, and the existence of community ties (Akay, Bargain, \& Zimmermann, 2012) .

Lee (1966) also revealed that the migration process was influenced by four factors: individual factors, factors found in the area of origin, factors found in the destination area, and obstacle between the area of origin and the destination.

\section{Individual Factors}

Individual factors that influence the occurrence of migration that are intended by Lee are internal factors within a person that are the basis for migrating or not. Individual factors that will assess the positive or negative of a destination area and who will decide whether he will move from the area of origin or remain.

In accordance with the statement of the Head of the Ambon City Population and Civil Registration Service in an interview (personal communication, January 25, 2015) that "I have observed so far, every resident who migrates to Ambon city to get a more decent education, work that is in line with education he/she has, and also to fulfill his economic needs." This is a personal desire to get a more decent life, which can be said as an individual factor in migrating to Ambon City.

Education in the city is indeed very different from that of the village, as in the city there is a lot of information available and also the worldwide internet today. However, in the village, it is not like that, maybe even the opposite. In the village, there is a commitment to get education, even though they rarely get information about the events in this world, and also they are competing to get more education than those in the city. Many villagers go to the city to continue their studies with the aim of getting a higher education. For sure they will be happy with the school in the city because of the information obtained in it (Anas, Riana, \& Apsari, 2015).

\section{Factors found in the area of origin}

The factors found in the area of origin, according to Lee, consist of positive and negative factors. In the area of origin, there are usually more negative factors than positive factors. Regarding factors in the area of origin of the Head of the Ambon City Population and Civil Registration Service in an interview (personal communication, January 25, 2017) that residents from around the Ambon city area migrated more to Ambon because the facilities needed were not available in the area. If we visit the Regency/City area around the city of Ambon, the construction of public facilities infrastructure is still far from expected. No wonder many people choose to come to Ambon City because basically every human being will try to meet their needs to survive.

\section{Factors Existing in the Destination Area}

Factors found in the destination area have positive and negative factors. However, in the 
destination, positive factors are more dominant than negative factors, which are the driving factors for someone to come to the destination.

In the opinion of the Head of the Population Supervision and Control Division (personal communication, January 23, 2017), "Ambon City is the Capital of the Maluku Province. It is no wonder Ambon city is the center of the surrounding areas. The city of Ambon is an office center, trade center, education center, and entertainment center." Almost all the facilities needed are already owned by Ambon City. This is a positive value and an attraction for the residents around him to come to Ambon city.

\section{Obstacles Between Regions of Origin and Destination Areas}

The obstacles referred to by Lee are for example the cost of moving, the condition of the area that is difficult or easy to reach, and transportation facilities to the destination. The interview with the Head of the Population Monitoring and Control Section (personal communication, January 23, 2017) illustrates that: "Ambon City is very easy to reach with its various transportation facilities and is supported by advances in the transportation sector so that obstacles to distance and costs can be easily overcome." Maluku Province is an archipelago; however, with the progress of vulnerable transportation equipment to get to Ambon City very briefly. The progress of public transportation supported by adequate development in Ambon City minimized obstacles from the area of origin to Ambon City. No wonder this caused residents around Ambon City to easily and compete to come to Ambon City.

According to Blacket (as cited in Kartiki, 2011), Migration occurs in response to multiple pressures, and it is difficult to isolate environmental pressures from ongoing economic ones. Thus, the effects of climate change increase the impetus towards migration, forcing people to go in search of safer environments that can offer them reliable livelihoods and household security.

Ambon City Population and Civil Registry Office in carrying out its role refers to Ambon Mayor Regulation No. 17/2009 (Ambon City's Government, 2009) concerning Job Description of the Structural Position in Ambon City Population and Civil Registration Office article 14 paragraph (2) section c and d, namely: Population Monitoring and Control Sector in charge of Coordinating the implementation of supervision of registration of Indonesian citizens and foreigners, and monitoring the flow of urbanization of the population, and supervising the registration of the flow of mobility of residents of Indonesian citizens and foreigners at each entrance of the city.

In an interview, the chief division of the Population Monitoring and Control explained (personal communication, January 23, 2017) that the agency supervised the registration process by supervising the moving of certificates used by the residents to process their transfer to Ambon City. The supervision in question is related to the validity of the data provided by the residents. Regarding the monitoring of urbanization, the section chief explained that the department carried out a few inspections of residents in the night club and boarding houses.

Furthermore, the chief of the Population and Civil Registration Office (personal communication, January 25, 2017) explained that he often ordered the inspection of residents in nightclubs and boarding houses to check their IDs because some of them are quite often not having documentation for being Ambon resident. This inspection had been carried out together with the Civil Service Police Units from Ambon City Government Section, Ambon City Legal Section, Commission I Regional People's Representative Assembly Ambon City (DPRD), and the Population and Civil Registration Service Officers. The aims of this action are to find out from the entire population living in the area how many immigrants have 
or have not had ID with them and have either reported, or not, themselves to the office. The incident also happened in China, where the apparatus carried out to check the completeness of ID Cards, and there were several other cases carried out by migrants, based on the results of the research (Zhao, 2005).

The following table is data that has been collected by the population and civil records office in carrying out its duties to record the population by carrying out an inspection in a boarding house so that we can see that the migration in Ambon City is very high.

Several empirical studies investigated the impact of migration on rural households' welfare but with ambiguous results. Evidence from Thailand suggests that migration reduces income inequality, mainly through changes in the distribution of productive assets (Garip, 2014). Another study from Thai-land reveals that poor rural households tend to produce poor migrants, which could be one of the reasons for the continued existence of a wide rural-urban gap in welfare (Amare et al., 2012). Similarly, Azam \& Gubert (2006) report findings from Mali and Senegal, according to which remittances cause rural households to reduce their work effort, which reduces the effectiveness of migration as a poverty reduction instrument. Household panel data from Mexico for the period 1998-2000 used to assess how likely households with a high level of vulnerability to poverty receive remittances. However, contrary to the expectation, households with a higher level of vulnerability to poverty have a lower probability to receive remittances (de la Fuente, 2010).

Migrants are usually dominated by people from Java and North Sulawesi. This population is reported by the Population Office to be a non-permanent resident. After the population data, a replacement identity card as proof that the concerned resident has reported is given. This identity card based of the Minister of Home Affairs Regulation No. 14 of 2015 (Government Of The Republic Of Indonesia, 2015), concerning Guidelines for Collecting Non-Permanent Population Data in Article 3 paragraph 1 and 2 only valid for 6 months; if within 6 months the population wishes to settle in Ambon, he must arrange the process of transferring to Ambon.

Minister of Home Affairs Regulation No. 14/2015 (Government Of The Republic Of Indonesia, 2015) concerning Guidelines for Data Collection for Non-Permanent Residents Article 20 regulates the responsibilities of the Regent/Mayor through the Department of Population and Civil Registration, explaining that:

"Regents/Mayors, through the Department of Population and Civil Registration, are responsible for: Carrying out data collection

Table 4.

Data recap population in boarding house

\begin{tabular}{|c|c|c|c|c|c|c|c|c|c|c|c|c|c|c|c|}
\hline \multirow[b]{2}{*}{ No. } & \multirow[b]{2}{*}{$\begin{array}{c}\text { Name } \\
\text { Sub-District }\end{array}$} & \multirow{2}{*}{$\begin{array}{c}\text { Total } \\
\text { Place } \\
\text { of } \\
\text { Kos }\end{array}$} & \multicolumn{3}{|c|}{ Amount of Souls } & \multicolumn{4}{|c|}{$\begin{array}{l}\text { Number of Population } \\
\text { Documents (ID Card) Owned }\end{array}$} & \multicolumn{4}{|c|}{$\begin{array}{c}\text { Number of Reasons Come to } \\
\text { Ambon }\end{array}$} & \multicolumn{2}{|c|}{$\begin{array}{c}\text { Total Types } \\
\text { of Violations } \\
\text { are Done }\end{array}$} \\
\hline & & & M & F & Total & $\begin{array}{l}\text { ID Card } \\
\text { Ambon }\end{array}$ & $\begin{array}{l}\text { Other } \\
\text { Regional } \\
\text { Id Card }\end{array}$ & $\begin{array}{c}\text { Do Not } \\
\text { Have a } \\
\text { KTP }\end{array}$ & Total & Work & Education & Etc & Total & $\begin{array}{c}\text { Do Not } \\
\text { Have A } \\
\text { Moving } \\
\text { Letter } \\
\text { Come }\end{array}$ & Etc \\
\hline 1 & Sirimau & 324 & 986 & 1,178 & 2,164 & 479 & 1.053 & 632 & 2,164 & 951 & 829 & 384 & 2,164 & 1,167 & 518 \\
\hline 2 & Nusaniwe & 89 & 280 & 303 & 583 & 143 & 190 & 250 & 583 & 277 & 180 & 126 & 583 & 428 & 12 \\
\hline 3 & Ambon Bay & 276 & 1,049 & 1,195 & 2,244 & 224 & 627 & 1,393 & 2,244 & 221 & 2,001 & 22 & 2,244 & 2,020 & - \\
\hline 4 & Baguala & 76 & 246 & 336 & 582 & 113 & 211 & 258 & 582 & 210 & 289 & 83 & 582 & 211 & 258 \\
\hline & TOTAL & 765 & 2,561 & 3,012 & 5,573 & 959 & 2,081 & 2,533 & 5,573 & 1,659 & 3,299 & 615 & 5,573 & 3,826 & 788 \\
\hline
\end{tabular}

Source: Ambon City's Population and Civil Registration Department 2017 
on non-permanent residents; Processing and presenting nonpermanent population data; Carry out socialization of non-permanent population data collection policies to officials and partners; Coordinate with local governments from nonpermanent residents and partners; Carry out monitoring, evaluation and reporting of non-permanent population data collection."

Based on the information from the head of the Population and Civil Registration Office and Head of the Ambon City Population Control Section, the official has implemented the five points above. In an effort to control migrating, official population does data collection by carrying out inspection, then the data is processed and recorded.

Based on Article 21 of the Minister of Home Affairs Regulation No. 14/2015, concerning Guidelines for Data Collection of Non-Permanent Residents regulating the responsibilities of Regents/Mayors through the Department of Population and Civil Registration, namely:

Paragraph (1) “The implementation of data collection on non-permanent residents shall be further regulated by Regulations of Regents/Mayors." Paragraph (2) "Regulations of the Regent/Mayor as referred to in paragraph (1) shall at a minimum contain: Right and the obligations of non-permanent residents; The roles and responsibilities of the Management of RT and RW or other designations in the data collection of non-permanent residents; The role and responsibility of partners in the data collection of non-permanent residents; The mechanism of coordination of the implementation, control and reporting of nonpermanent population data collection; Register non-permanent population settings; and Processing, presentation and use of data can be used by non-permanent residents in the planning, implementation and control of local development."

Until now, government of Ambon are yet to have any legislation governing the nonpermanent population census. Coordination in the form of controlling the population is not contained in a clear and legal force. According to Levinson in Soekanto (2010, p. 213), the role includes three things: norms that are related to a person's position or place in society; the role in this sense is a series of rules that guide a person in community life; and the role is a concept of what can be done by individuals in society as an organization.

The series of regulations carried out by the office consisted of the highest regulations to the lowest regulations, namely regulations on population administration, regulations on guidelines for data collection on non-permanent residents, and regulations on job descriptions of structural positions in Ambon City Population and Civil Registration Service. This regulation is a guideline of all roles that will be performed by each part of the Service. This regulation is the norm associated with the position of the Service in the community. In this regulation, there is also a series of regulations that guide the agency in acting in the community.

Furthermore, Soekanto (2010, p. 215) cites

Marion J. Levy's opinion on roles, namely:

"Discussion of the various roles inherent in individuals in society is important for the following: A certain role must be carried out if the community structure is to be sustained. The role of terse but should be attached to individuals who are considered by the community to be able to carry it out. They must first practice and have the desire to carry it out. In the community, sometimes, individuals are found unable to carry out their roles as expected by the community because it may require the sacrifice of the meaning 
of too many personal interests; if everyone is able and able to carry out its role, not necessarily the public can provide well-balanced opportunities. In fact, it is often seen how people are forced to limit these opportunities."

The role of the Ambon City Population and Civil Registration Service in accordance with Ambon Mayor Regulation No. 17/2009 (Ambon City's Government, 2009) article 14 paragraph 2 letter (c) and letter (d) is to coordinate the monitoring of population urbanization, supervise the registration of population mobility, especially in this case controlling the population who immigrated to Ambon City, namely: (1) Supervise the flow of mobility in the form of supervision of moving certificates used by the community to process their transfer to Ambon City. The supervision in question is related to the validity and completeness of the population data, (2) Inspection residents, especially at karaoke and boarding houses; this inspection is done with the Civil Service Police Unit, Ambon City Government Section, Ambon City Legal Section, Commission I Regional People's Representative Assembly Ambon City (DPRD), and the Population and Civil Registration Service Officers, in an effort to curb residents who do not have identity card (KTP) and are already affected by inspection but not yet aware of the applicable population regulations. (3) The Ambon City Government, through its regional apparatus from the urban village, sub-district, and even the city levels, through the Population and Civil Registration office, always provided information on the importance of population reporting.

But in carrying out the role above of the Population and Civil Registration office, Ambon City faced several obstacles in controlling migration namely: (1) Most of the residents who migrated to Ambon City did not report themselves to the Population and Civil Registration Office so that the Office had difficulty monitoring the flow of urbanization and supervision of population mobility, (2) The people affected are not under supervision, but in fact it has not been counted 6 months after the data collection; the residents are not aware of their existence because they are moving again to other areas. This population is mostly night workers from different regions so that they do not have a place to stay clear, (3) There is no effort and awareness of the people who have been in inspection and under supervision for change by reporting personal data to the government. The results of the research carried out the factors that influence migration in Ambon City, namely the existence of complete facilities in Ambon city, both from entertainment, trade, education, tourism objects, transportation, and office and government center.

\section{Conclusion}

The role of Ambon City's government is very important for controlling incoming migration. Ambon City's Government, through the Population and Civil Registration Office, has carried out its duties as regulated by the Mayor of Ambon Regulation No. 17/2009 article 14 paragraph 2 letters (c) and letter (d), namely: Coordinating the monitoring of urbanization of population and Supervising the registration of population mobility flows. However, to implement the main tasks and functions, they encountered several obstacles, namely: Most of the residents who migrated to Ambon City did not report themselves to the Population and Civil Registration Office so that the Office had difficulty monitoring the flow of urbanization and supervision of population mobility; The people affected are not under supervision, but in fact it has not been counted 6 months after the data collection, the residents are not aware of their existence because they are moving again to other areas. This population is mostly night workers from different regions so that they do not have a place to stay clear; There 
is no effort and awareness of the people who have been in inspection and under supervision for change by reporting personal data to the government.

Based on the above conclusions, author propose some suggestions to control incoming migrations occurred in Ambon City, that the government should make development equality or facilities in the regency/cities in Maluku so that the community is not concentrated in Ambon City and regulations related to population movements and stricter sanctions to residents who do not comply with these regulations. Given the importance of this population problem, the government should conduct a coordination meeting from the urban village sub-district level at least once every two months in the context of discussions about the population including migration.

Rahmawati Sururama is an active lecturer in the Department of Local Government Administration, Faculty of Government Management, Institut Pemerintahan Dalam Negeri. She earned her doctorate at Manado State University in 2017. In addition to being a lecturer, she also served as head of the department of local government administration. There are several studies, books, and journals that she has written, including the Implementation of the Development of Human Resources for Educators at the Academy of Nursing at the Rumkit Tkt. III Teling Manado North Sulawesi (2018), Revitalization of the Population Program in the Context of Suppressing Population Fertility in Indonesia (2016), Indonesian Government Leadership (2016), etc.

Tiara Nanuru is a civil servant. After completing her bachelor's degree at the Institute of Pemerintahan Dalam Negeri, she worked as a staff in the field of performance and apparatus discipline in the regional staffing office, North Maluku province. She is currently completing a master's education in Human Resource Management department.

\section{References}

Akay, A., Bargain, O., \& Zimmermann, K. F. (2012). Relative concerns of rural-to-urban migrants in China. Journal of Economic Behavior and Organization, 81(2), 421-441. doi: 10.1016/j.jebo.2011.12.006

Amare, M., Hohfeld, L., Jitsuchon, S., \& Waibel, A. H. (2012). Rural-urban migration and employment quality: A case study from Thailand. Asian Development Review, 281(1), 57-59.

Ambon City's Goverment. (2009). Job description of structural position in Ambon City population and civil registration service (No. 17/2009). Ambon: Ambon City's Government.

Anas, A. Y., Riana, A. W., \& Apsari, N. C. (2015). Desa dan kota dalam potret pendidikan. Procceding Penelitian aan Pengabdian Kepada Masyarakat. Sumedang: Departemen Kesejahteraan Sosial, Universitas Padjajaran. Retrieved from https://jurnal. unpad.ac.id/prosiding/article/view/13592

Anh, N. T., Rigg, J., Huong, L. T. T., \& Dieu, D. T. (2012). Becoming and being urban in Hanoi: Rural-urban migration and relations in Viet Nam. Journal of Peasant Studies, 39(5), 1103-1131. doi: 10.1080/03066150.2011.652618

Azam, J. P., \& Gubert, F. (2006). Migrants' remittances and the household in Africa: A review of evidence. Journal of African Economies, 15(2), 426-462 .doi.org/10.1093/ jae/ej1030

Badan Pusat Statistik. (2016). Penduduk provinsi Maluku menurut Kabupaten Kota. Retrieved June 25, 2018, from https://maluku. bps.go.id/statictable/2016/09/14/179/ penduduk-provinsi-maluku-menurutkabupaten-kota-1961---2020.html

Badan Pusat Statistik. (2010). Penduduk menurut wilayah, jenis kelamin, dan status migrasi seumur hidup Propinsi Maluku. Retrieved June 25, 2018, from https:// sp2010.bps.go.id/index.php/ site/ tabel? tid $=324 \&$ wid $=8100000000$ 
Badan Pusat Statistik. (2010). Penduduk 5 tahun keatas menurut wilayah, jenis kelamin, dan status migrasi Risen, Provinsi Maluku. Retrieved June 25, 2018, from https:// sp2010.bps.go.id/index.php/site/tabel?sea rchtabel=Penduduk+5+Tahun+Keatas $+\mathrm{Me}$ nurut+Wilayah\%2C+Jenis+Kelamin $\% 2 \mathrm{C}+\mathrm{d}$ an+Status+Migrasi+Risen\&tid $=272 \&$ search

Black, R., Adger, W. N., Arnell, N. W., Dercon, S., Geddes, A., \& Thomas, D. (2011). The effect of environmental change on human migration. Global Environmental Change, 21(1), S3-S11. doi: 10.1016/j. gloenvcha.2011.10.001

Dinas Pariwisata Maluku. (2018). Jumlah kunjungan wisatawan ke Maluku meningkat 20 Persen. Retrieved August 30, 2019, from https://kumparan. com/ambonnesia/ jumlah-kunjunganwisatawan-ke-maluku-meningkat-20persen-153556061261076169

de Brauw, A., \& Harigaya, T. (2007). Seasonal migration and improving living standards in Vietnam. American Journal of Agricultural Economics, 89(2), 430-447. doi: 10.1111/j.1467-8276.2006.00989.x

DeHaas, H. (2010). Migration and development: A theoretical perspective. International Migration Review, 44(1). doi: 10.1111/j.17477379.2009.00804.x

de la Fuente, A. (2010). Remittances and vulnerability to poverty in rural Mexico. World Development, 38(6), 829-839. doi: 10.1016/j.worlddev.2010.02.002

Duverger, M. (2010). Sosiologi politik. Jakarta: PT. Rajagrafindo Persada.

Garip, F. (2014). The impact of migration and remittances on wealth accumulation and distribution in Rural Thailand. Demography. Rtrieved from https://doi. org/10.1007/s13524-013-0260-y

Government of The Republic of Indonesia. (2006). Population Administration (No.23/2006). Jakarta: Government of The Republic of Indonesia
Hartmann, B. (2010). Rethinking climate refugees and climate conflict: Rhetoric, reality and the politics of policy discourse. Journal of International Developmen, 22(2), 233-246. doi: 10.1002/jid.1676

Haug, S. (2008). Migration networks and migration decision-making. Journal of Ethnic and Migration Studies, 34(4), 585-605. doi: 10.1080/13691830801961605

Kartiki, K. (2011). Climate change and migration: A case study from rural Bangladesh. Gender and Development, 19(1), 23-28. doi: 10.1080/13552074.2011.554017

Kusuma Y. S., Pandav, C. S., Babu, B. V. (2014). Socio-demographic profile of socioeconomically disadvantaged internal migrants in Delhi. Journal of Identity and Migration Studies, 8(2), 37-49.

Labolo, M. (2011). Memahami ilmu pemerintahan. Jakarta: PT. Rajagrafindo Persada.

Lee, E.S. (1966). A theory of migration. Demography, 3(1), 47-57. doi: 10.2307/2060063

Lumbantoruan, W. (2009). Analisis migrasi penduduk ke Desa Ndokumsiroga Kecamatan Simpang Empat Kabupaten Karo. Journal Geografi, 1(1), 43-49.

Mantra, I. B. (2013). Demografi Umum. Yogyakarta: Pustaka Pelajar.

Minister of Home Affairs. (2015). Guidelines for registration of Non-German Residents (No. 14/2015). Jakarta: Minister of Home Affairs

Nguyen, L. D., Raabe, K., \& Grote, U. (2015). Rural-urban migration, household vulnerability, and welfare in Vietnam. World Development, 71(C), 79-93. doi: 10.1016/j. worlddev.2013.11.002

Sunarto, Hs. (1991). Dampak migrasi sirkuler terhadap desa asal migran. Jurnal Populasi, 2(2), 37-44. doi: 10.22146/jp.10805

Soekanto, S. (2010). Sosiologi suatu pengantar. Jakarta: PT. Rajagrafindo Persada.

Sugiyono. (2015). Metode penelitian manajemen. Bandung: Alfabeta.

Syafiie, I. K. (2011). Etika Pemerintahan. Jakarta: PT Rineka Cipta. 
Rahmawati Sururama, Tiara Nanuru: The Role of the Ambon City's Population and Civil Registration Office in Controlling Incoming Migration

Todaro, Michael P. (1979). Economic for developing world, introduction to a principles problems and policies. Hongkong: Longman
Zhao, Y. (1999). Labor migration and earnings differences: The case of rural China. Economic Development and Cultural Change. 47(4), 762-782. doi: 10.1086/452431 